\title{
THE EXPERIMENTAL IDENTIFICATION OF TORSIONAL ANGLE ON A LOAD-CARRYING TRUCK FRAME DURING STATIC AND DYNAMIC TESTS
}

\section{IDENTYFIKACJA EKSPERYMENTALNA KĄTA SKRĘCENIA USTROJU NOŚNEGO POJAZDU PODCZAS TESTU STATYCZNEGO I DYNAMICZNEGO*}

\begin{abstract}
The underframe of a truck is one of the most loaded parts of a vehicle. It is a spatial unit and it must be strong enough to withstand random loading within many years of maintenance. The most severe form of deformation is in torsion. So, frame side members are often made from elements with channel sections, rigid for bending and flexible for torsion. Authors have conducted the research of $6 \times 6$ high mobility wheeled vehicle assigned to 20-feet container. Their load-carrying structure is made from two separate underframes: longitudinal and auxiliary connected with bolted joints. The goal of the research was to check if the torsional angle of deformation of the underframe during static and dynamic tests is within an acceptable range. The static test was carried out for the main underframe first to assess the characteristic of torsional stiffness without the auxiliary frame. After connecting both frames together the measure was conducted again. In the experiment the diagonal wheels were lifted up and the resulting displacement of the ends of the frame side members was recorded. Simultaneously the strain at chosen points of the underframe was measured with a system of turned half bridge strain gauges. After calibrating the measuring system a second part of experiment was conducted within proving ground tests when the vehicle was fully loaded. The collected strain data at chosen points allowed for calculating the resultant displacement of the ends of the frame side members in function of sort of road and to indicate the influence of auxiliary frame on increasing the torsional stiffness of the underframe.
\end{abstract}

Keywords: underframe of vehicle, experimental measurements, numerical modeling, vehicle testing.

\begin{abstract}
Ustrój nośny pojazdu jest jednym z jego najbardziej obciążonych zespołów konstrukcyjnych. Jest to zespół o złożonej budowie przestrzennej, który musi być wystarczająco wytrzymały by wytrzymać zmienne obcią̇enia przez wiele lat eksploatacji pojazdu. Najbardziej obciązające sq te obciążenia które wywotuja skręcanie ustroju nośnego. Stąd ustrój nośny składa się najczęściej z podlużnic połączonych poprzeczami co w efekcie zapewnia duża sztywność na zginanie i podatność na skręcanie. W artykule przedstawiono badania podwozia pojazdu kołowego wysokiej mobilności $6 x 6$ przeznaczonego do połaczenia z kontenerem 20stopowym. Ustrój nośny pojazdu składa się z ramy głównej połaczonej za pomoca połaczeń podatnych z rama pośrednią. Celem badań było sprawdzenie czy kąt skręcenia ustroju nośnego pojazdu w badaniach statycznych i dynamicznych nie wywoluje naprężeń wykraczających poza zakres dopuszczalny. Test statyczny zostat przeprowadzony najpierw tylko do ramy gtównej w celu wyznaczenia jej sztywności skrętnej. Następnie ramy zostały połaczone i wyznaczenie sztywności zostało powtórzone. W ramach testu koła znajdujące się w pojeździe po przekątnej zostały podniesione aż do utraty kontaktu z podłożem. Równocześnie rejestrowano przemieszczenie końców podlużnic ramy i odksztalcenia w wybranych punktach, w których naklejono tensometry. Po skalibrowaniu ukladu pomiarowego przeprowadzono szereg testów przebiegowych z pojazdem całkowicie obciązonym tadunkiem. Zarejestrowane wartości odkształceń wykorzystano do wyznaczenia odkształcenia wypadkowego końców podlużnic ramy w funkcji rodzaju drogi oraz wpływu zamocowania kontenera na wypadkowa sztywność skrętnq ustroju pojazdu.
\end{abstract}

Slowa kluczowe: ustrój nośny pojazdu, badania eksperymentalne, modelowanie numeryczne, testy pojazdu.

\section{Introduction}

A loads that have an influence on a lorry during its ride are various in general and depends on a road condition $[6,8,12]$. The designer has been use the proper factor of safety that allows the structure of a vehicle to tolerate random loads if the level of loads are known in advance $[7,14]$. So the sort of road for planned rides has to be established at the beginning of the design process. The factor of safety should be limited to avoid oversizing the structure. In this case the permissible sorts of road have to be limited as well. From this perspective the quality assessment of design the underframe of high mobility lorry was conducted [11]. The vehicle's chassis taken into investigation was $6 \times 6$ and was designed to carry the 20 -feet container (Fig. 1). The rigid container was design to be connected with the chassis in four points with use an quick disconnect coupling. Because of that the susceptibility of underframe to torsion was significantly limited.

The lorry was built by JELCZ-KOMPONENTY Ltd. on highmobility, heavy-weights, all-wheel-drive, 3-axle chassis version. The vehicle is adjusted to drive on and off roads and carry a 20 -feet container. The wheel base is $4400+1400$ [mm]. The approach and departure angles are as follow: 36 and $29\left[^{\circ}\right]$. The main frame of the chassis is made from two longitudinal members of a frame with channel sections with additional pads attached to the longitudinal and seven crossbars with open and close sections. The torsional section modulus is $\mathrm{J}_{\mathrm{m}}=363\left[\mathrm{~cm}^{3}\right]$. The container is a rigid spatial object, so only in the middle part of a frame the torsional deformation in elastic range should be accessible. To make this real the tubular crossbeams were used (Fig. 2).

(*) Tekst artykułu w polskiej wersji językowej dostępny w elektronicznym wydaniu kwartalnika na stronie www.ein.org.pl 


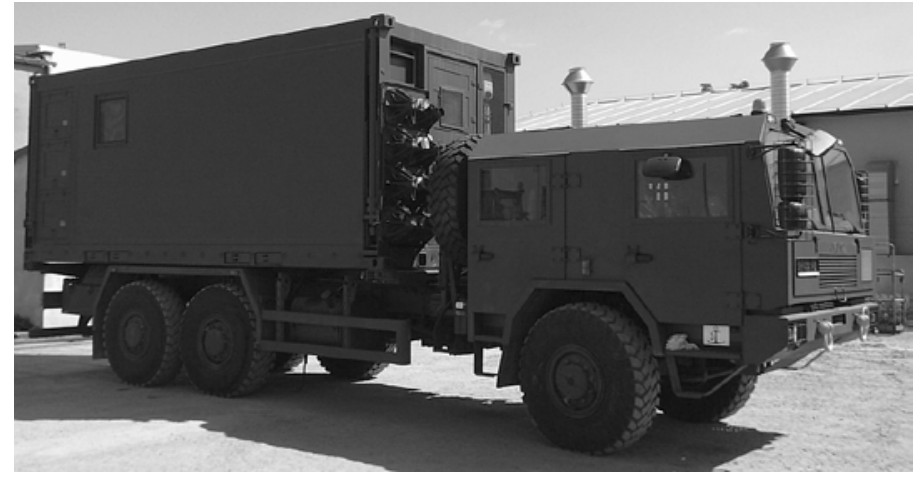

Fig. 1. The general view of investigated vehicle

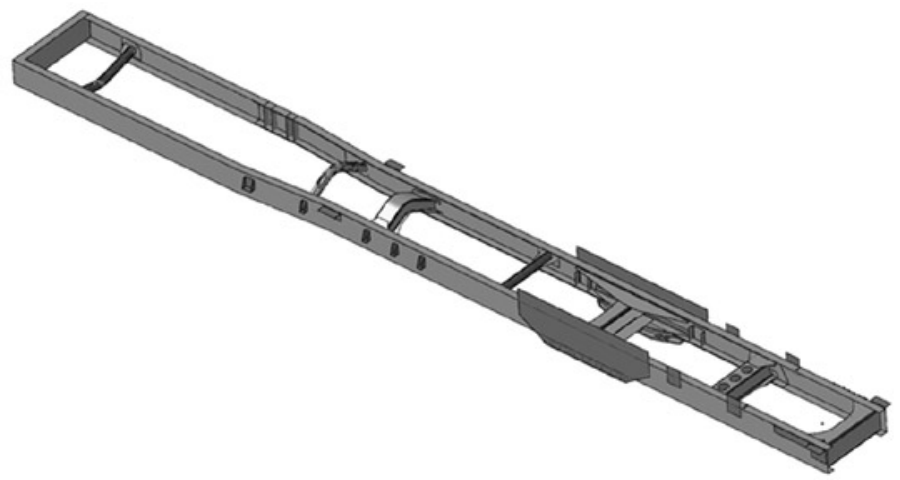

Fig. 2. Main chassis frame of the vehicle

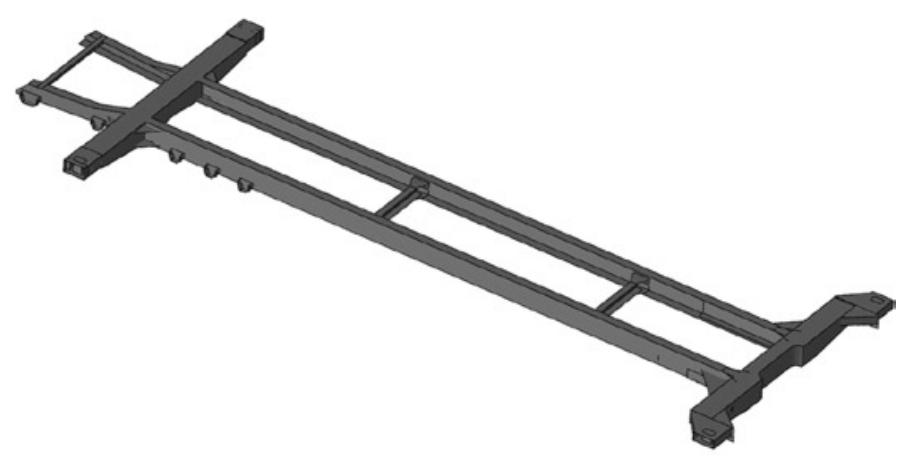

Fig. 3. The auxiliary frame

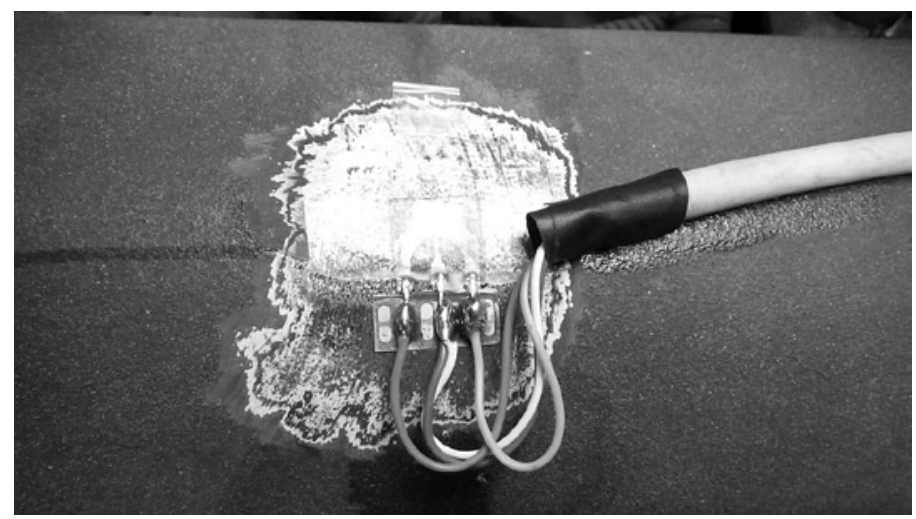

Fig. 7. Strain gauge in measure point $T 7$

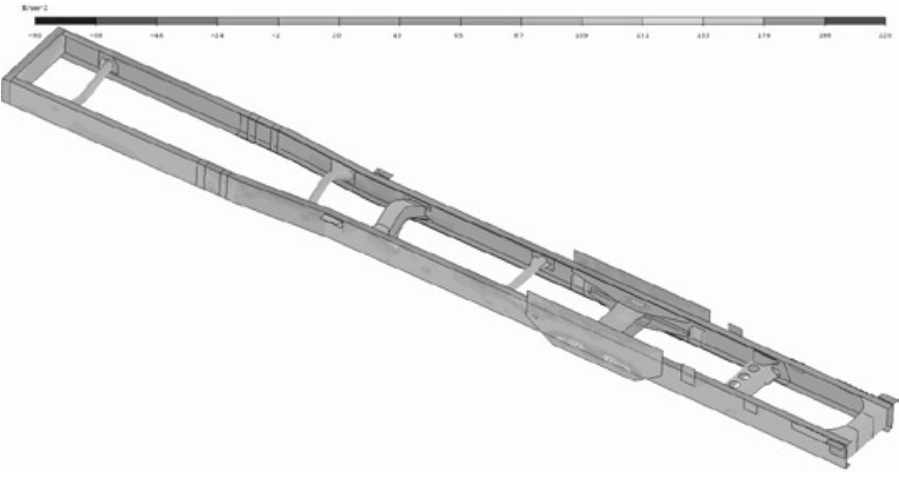

Fig. 4. Principal stress value within a main frame

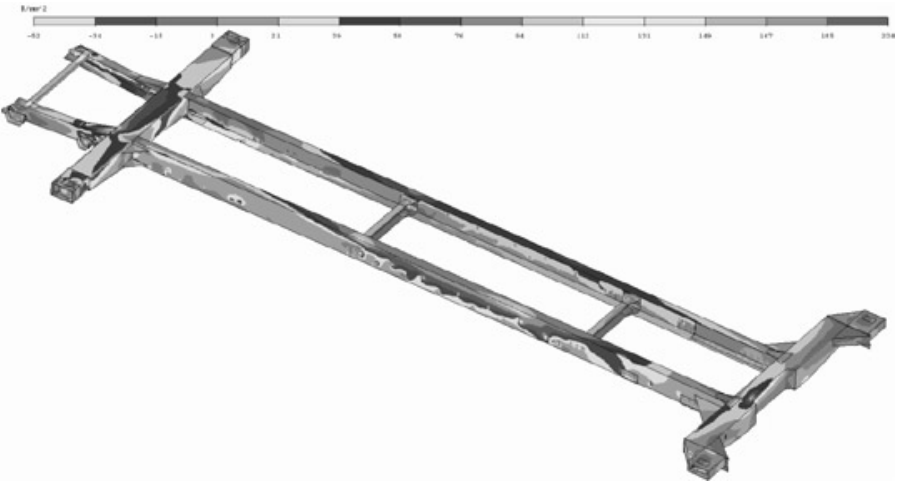

Fig. 5. Principal stress value within a auxiliary frame

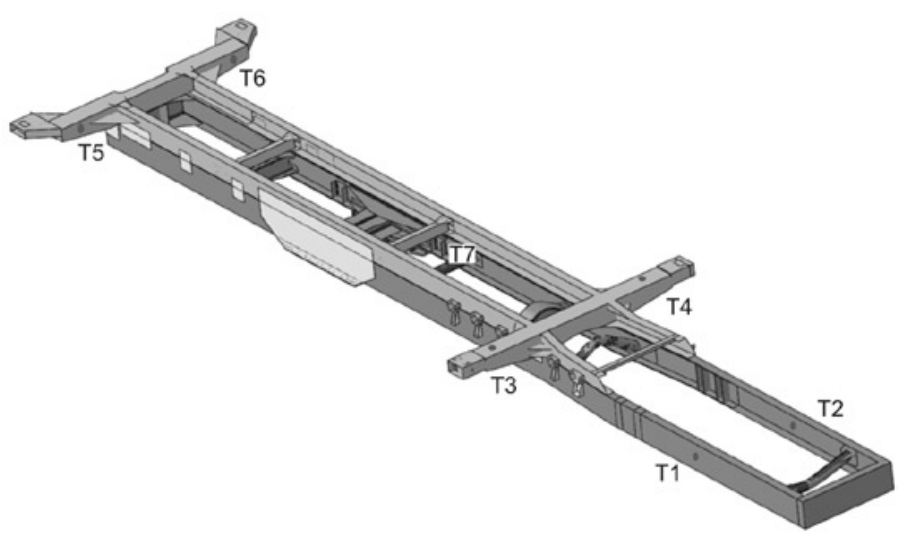

Fig. 6. Points of location the gauges on main and auxiliary frame

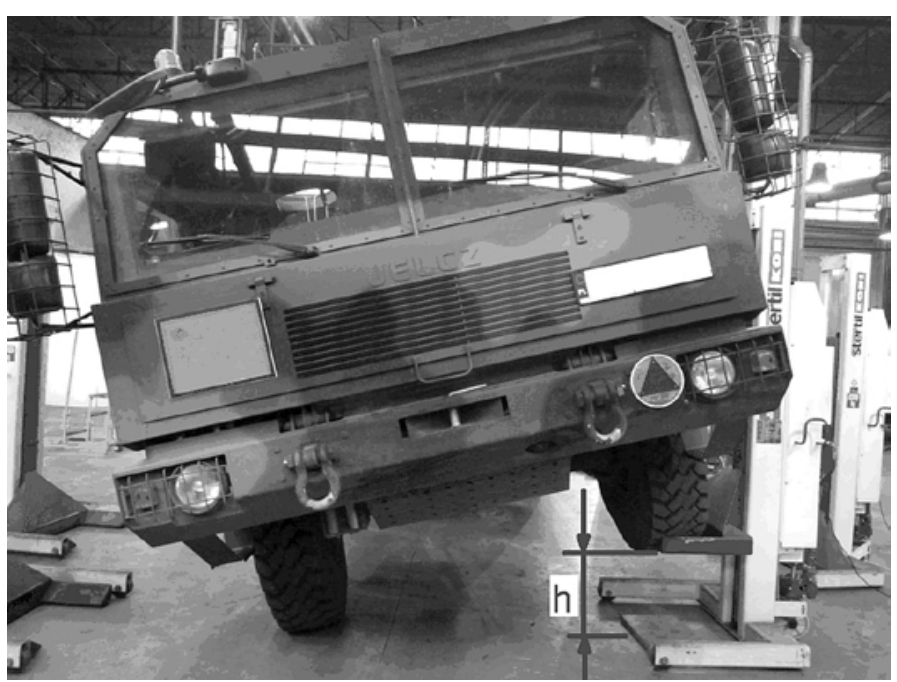

Fig. 8. A view of vehicle during a measurement 
To make the part of a main frame rigid enough to join it with the container the auxiliary frame was created which the longitudinal members were with channel section (Fig. 3). Ends of longitudinal members of auxiliary frame are jointed to each other with bolts. The close-section beams have been specially designed to achieve a nonlinear section modulus of bending. This auxiliary frame increases the torsion section modulus by $\mathrm{J}_{\mathrm{a}}=149\left[\mathrm{~cm}^{3}\right]$. Those frames have been connected to each other with use the flexible joints in the front and rigid in the rear part of the auxiliary frame.

\section{Selection of measurement points}

Firstly, in order to determine the measurement points of deformation of jointed frames the analysis of technical documentation was conducted. Any points were torsion or bending appears were selected. Then a shell FEM model $[10,15]$ of frames with a 256000 nodes of freedom was created and analysed. As a result of the analysis, the zones of uniform main stresses were found [5]. An examples of stress value within a main and an auxiliary frame were presented in figure 4 and 5 accordingly.

Finally, the measurements of deformation were conducted at the seven points presented in figure 6 . The three of them (T1, $\mathrm{T} 2, \mathrm{~T} 7)$ were placed on the main frame and the others (T3, T4, T5, T6) on the auxiliary frame [1, 3, 4] (Fig. 6).

\section{Measurement's arrangement}

To measure the deformation of frames the electric resistance wire strain gauges TFpxy-5/350 and TFx-6/350 were used [2] (Fig. 7). The resistance of them was $\mathrm{R}=350,5[\Omega] \pm 0,25$ [\%], with a constant $\mathrm{k}_{s g}=2,15 \pm 0,5$ [\%]. As a consequence of the use of inverted half bridge strain gauges is a decrease of their sensitivity $\mathrm{w}_{\mathrm{CH}}$ caused by a resistance of wires. This quantity was taken into account and a range of stress $\Delta \sigma_{i}$ was calculated as follow:

$$
\begin{gathered}
\Delta \sigma_{i}=\Delta \varepsilon_{i} \cdot E \\
\Delta \varepsilon_{i}=\frac{4 \cdot \Delta U_{i}}{U_{z m} \cdot w_{C H} \cdot k_{s g}}
\end{gathered}
$$

where: $\Delta \varepsilon_{\mathrm{i}}$ - range of recorded strain, $E$ - Young's module (E = 210 [GPa]), $\Delta U_{i}$ - range of voltage [V], $U_{z m}$ - power supply voltage $[\mathrm{V}], k_{s g}-$ constant of gauge, $w_{C H}-$ sensitivity of gauge.

\section{Experimental results}

The experimental measures of torsion on the underframe of the analyzed vehicle were investigated in three steps $[9,13,16]$ :

Static measures:

- the main frame only - step 1 ,

- the joined frames - step 2,

- Dynamic measure:

- the joined frames during a ride with a container - step 3.

As an external force in static measures a column hydraulic elevators were used that lifted a wheel or wheels until the unlifted wheels had a contact with a ground. During an experiment the front part of an underframe was loaded by a cabin and a rear part was loaded by a mass of a lifted axles, suspension and wheels (Fig. 8).

\subsection{Static measurements of main underframe}

Within a static measures of stress caused by a torsional deflection of underframe wheels of front and rear wheels were lifted up to a height of $600[\mathrm{~mm}]$. The algorithm of measure was as follows:
Table 1. The value of torsional angle of main underframe of vehicle ( $a$ - angle of twist the front bumper of a vehicle, $\beta$ - angle of twist the rear bumper of a vehicle, $F L$ - a front left wheel lifted 600 [mm], FR - a front right wheel lifted 600 [mm])

\begin{tabular}{|c|c|c|c|c||}
\hline \multirow{2}{*}{ Nr of measure } & $\alpha[\mathrm{deg}]$ & $\beta[\mathrm{deg}]$ & $\boldsymbol{\alpha}+\beta[\mathrm{deg}]$ & Notice \\
\hline 1 & -15.99 & 0 & 15,99 & only FL lifted \\
\hline 2 & 1.34 & 18.33 & 16,99 & only FR lifted \\
\hline 3 & 8.31 & 12.1 & 20,41 & lifted LF and RR \\
\hline
\end{tabular}

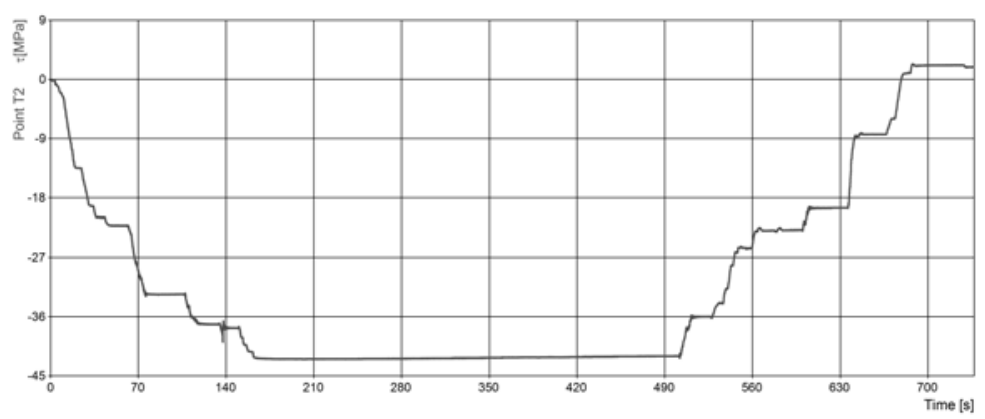

Figure 9. The range of shear stress in point $T 1$

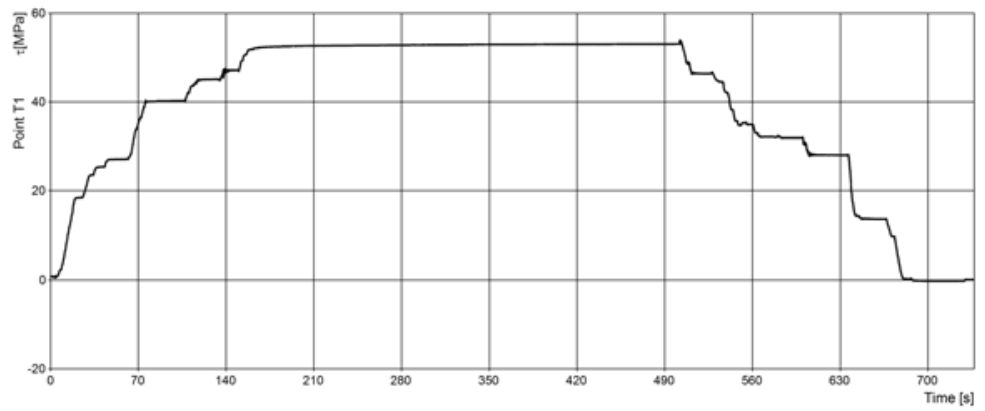

Figure 10. The range of shear stress in point $T 2$

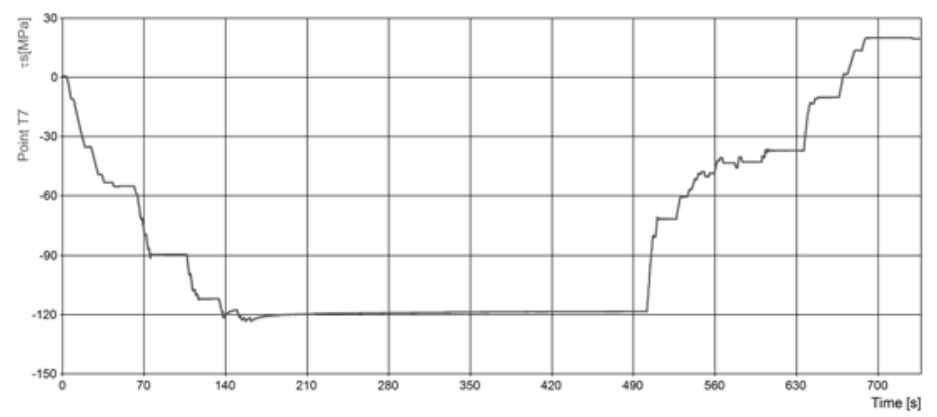

Figure 11. The range of torsional stress in point $T 7$

- front left wheel was lifting up to a 600 [mm],

- the middle right wheel was lifting up to 600 [mm] when a front left wheel was lifted,

- rear right wheel was lifting up to $600[\mathrm{~mm}]$ when a front and a middle wheel were lifted,

- finally all wheels were lowered to the start position.

Then the measure started from lifting a front rear wheel according to the algorithm described above. The main goal of experiment was to determine the maximum angle of torsion of the main underframe without an auxiliary frame. Results of the tests are presented in table 1. 
Table 2. The list of maximum sheer stress in chosen points of twisted jointed frames

\begin{tabular}{|c|c|c|c|}
\hline Nr of measure & $\begin{array}{c}\text { Point T1 } \\
\tau[\mathrm{MPa}]\end{array}$ & $\begin{array}{c}\text { Point T2 } \\
\tau[\mathrm{MPa}]\end{array}$ & $\begin{array}{r}\text { Point T7 } \\
\text { T[MPa] }\end{array}$ \\
\hline 1 & 38 & -22 & -85 \\
\hline 2 & 43 & -39 & -111 \\
\hline 3 & 53 & -42 & -118 \\
\hline
\end{tabular}

The range of a shear stress recorded in point T1, T2 and torsional stress in point T7 (measure $\mathrm{nr} 3$ ) is presented in Fig. 9-11.

Maximum value of twist angle of main underframe was 20,4 [deg], and a maximum sheer stress in points $\mathrm{T} 1, \mathrm{~T} 2$ and $\mathrm{T} 7$ was as follow: 83, -42 and 118 [MPa]. The list of recorded values of stress was presented in table 2 .

The calculated twist susceptibility of a jointed frames between front bumper and the last rear crossbar was $2,1[\mathrm{deg} / \mathrm{m}]$.

\subsection{Static measurements of jointed main and auxiliary frames}

The next part of experiment was to measure the stress caused by a torsional deflection of the jointed main and auxiliary frame in eight points placed in the front, middle and rear part of jointed frames. The positions of gauges are presented in figure 12. Points A and B were placed on the front metal bumper, $\mathrm{C}, \mathrm{D}, \mathrm{G}$ and $\mathrm{H}$ were placed on the rear container beam and $\mathrm{E}$ and $\mathrm{F}$ were placed on the front container beam. The algorithm of measure was described in paragraph 4.1 . The vehicle was unloaded. Results of tests are presented in table 3.

The total maximum twist angle was decreased by $37 \%$ in comparison to the case described in point 4.1 because of the auxiliary frame that was twisted of max. 6,8 [deg]. The twist angle between front bumper and front container beam was max. 5,4 [deg]. The main frame was twisted in maximum range near the front container beam. That was caused because the engine rigid for twisting is jointed to the frame in

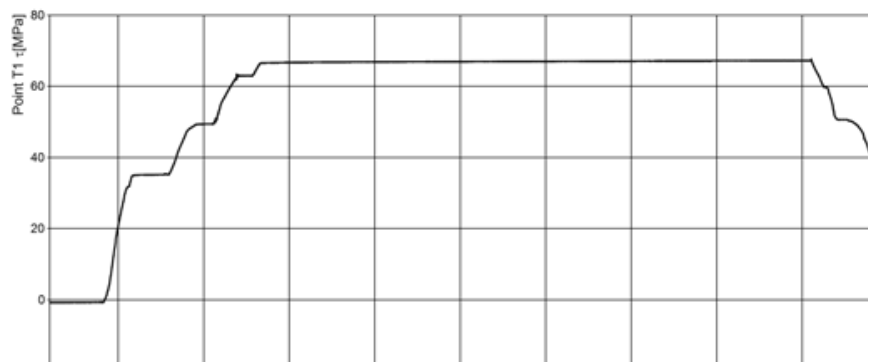

Fig. 13. The changes of shear stress in point $T 1$ when frames were maximally twisted

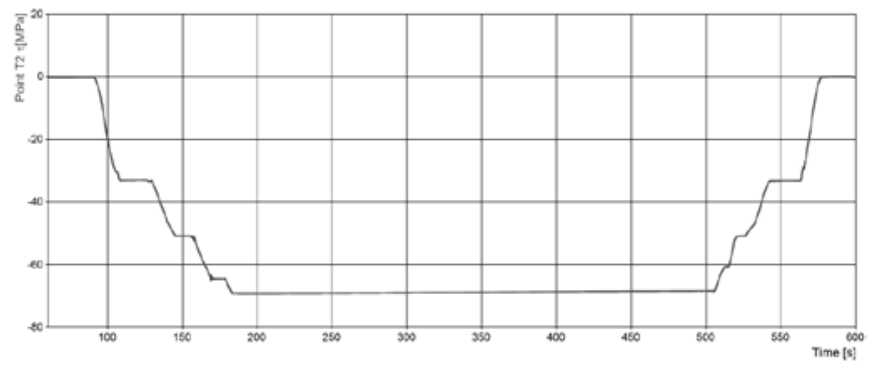

Fig. 14. The changes of shear stress in point T2 when frames were maximally twisted

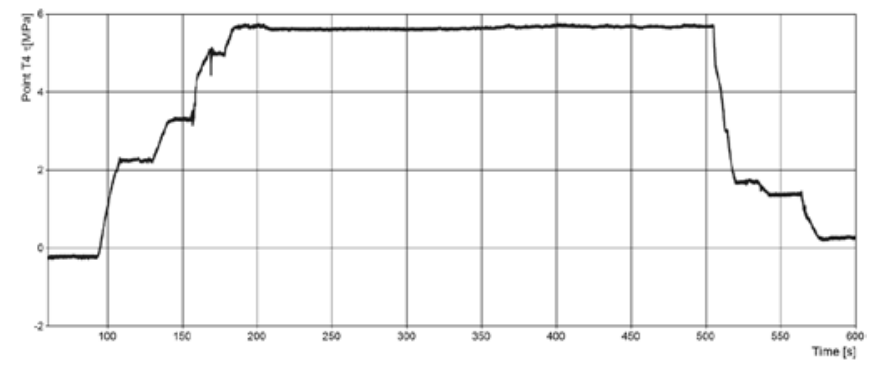

Fig. 15. The changes of shear stress in point T4 when frames were maximally twisted

the front part of it. The maximum twist angle of auxiliary frame was 9,4 [deg] when only one front wheel is lifted. The front container beam was loaded not only by bending, but also by torsion. So, the joint of frames should be rigid at the end of frames and susceptible in the middle zone (connection between front container beam and main frame).

The stress changes caused by twisting crossbar are presented in figures $13 \div 16$.

The maximum values of stress in chosen points are presented in table 4.

Recorded value of stress at points $\mathrm{T} 1$ and $\mathrm{T} 2$ was higher by about $50[\%]$ then when only the main frame

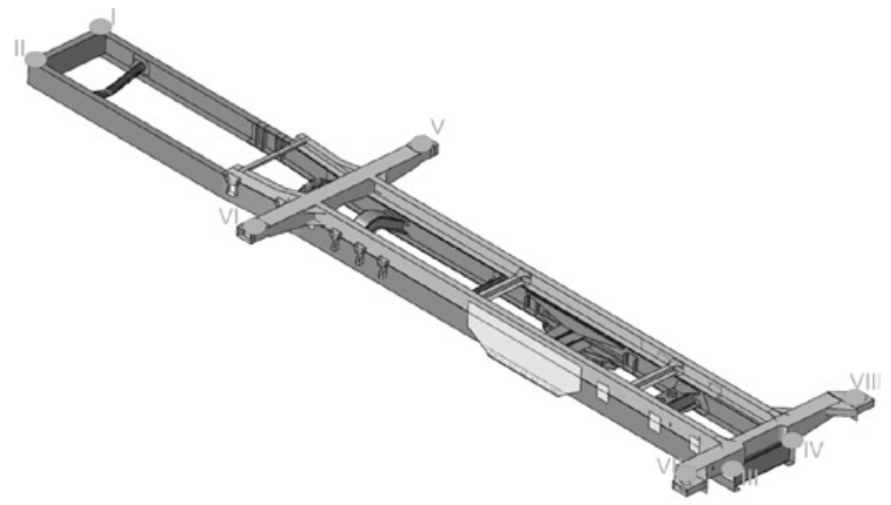

Fig. 12. Points of measurement the twist angle

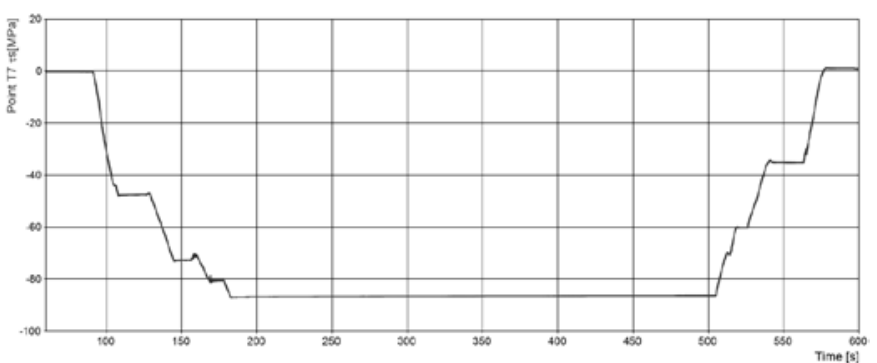

Fig. 16. The changes of torsional stress in point $T 7$ when frames were maximally twisted 
Table 4. Examples of stress value in chosen points when frames were maximally twisted

\begin{tabular}{|c|c|c|c|c|}
\hline $\begin{array}{l}\text { Nr of mea- } \\
\text { surement }\end{array}$ & $\begin{array}{c}\text { Point T1 } \\
\text { t[MPa] }\end{array}$ & $\begin{array}{l}\text { Point T2 } \\
\text { T[MPa }\end{array}$ & $\begin{array}{c}\text { Point T4 } \\
\text { T[MPa }\end{array}$ & $\begin{array}{c}\text { Point T7 } \\
\text { т[MPa }\end{array}$ \\
\hline 1 & 59 & -56 & 5 & -81 \\
\hline 2 & 59 & -61 & 4 & -65 \\
\hline 3 & 67 & -69 & 6 & -86 \\
\hline
\end{tabular}

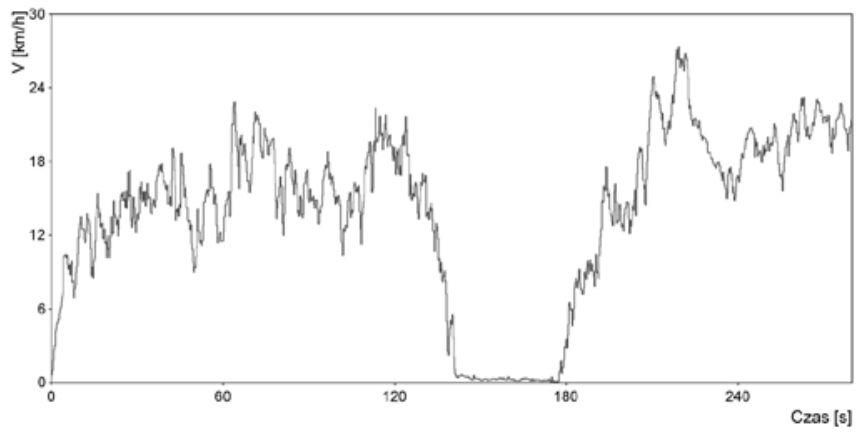

Fig. 17. An example of speed variability in off-road test

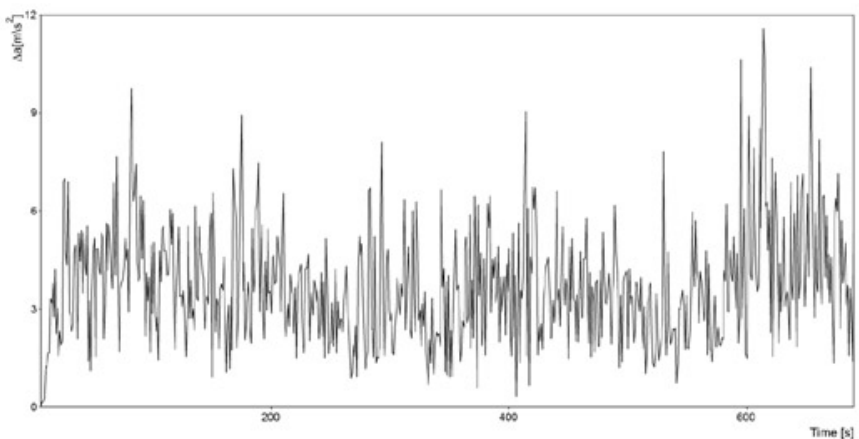

Fig. 18. The outcome value of vertical acceleration of container

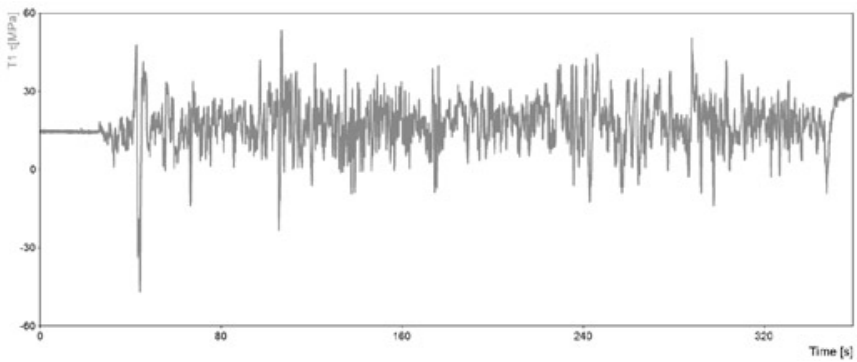

Fig. 19. Value of $\tau$ in point T1

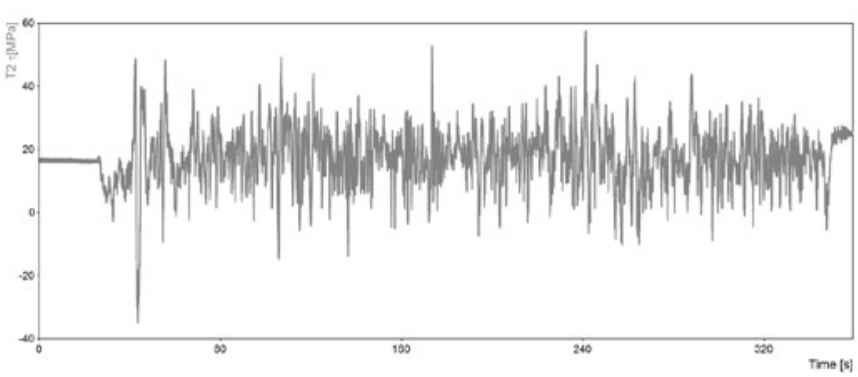

Fig. 20. Value of $\tau$ in point $T 2$

beam was $1,3[\mathrm{deg} / \mathrm{m}]$. The total twist susceptibility of the jointed frames between front and rear bumper was $3,8[\mathrm{deg} / \mathrm{m}]$.

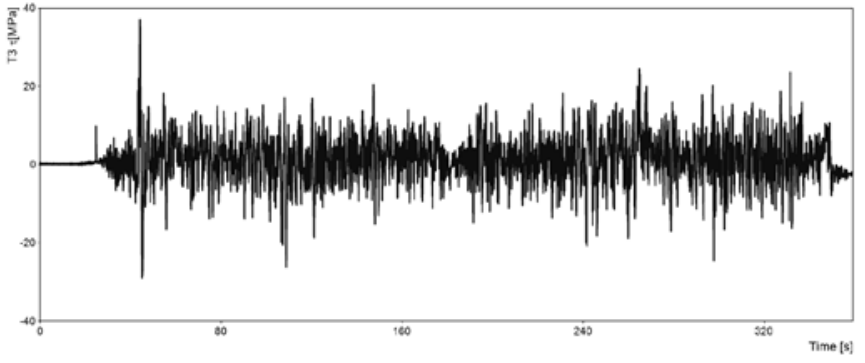

Fig. 21. Value of $\tau$ in point T3

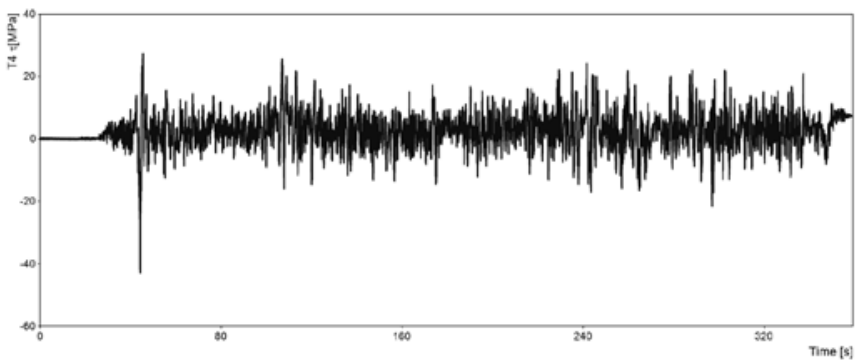

Fig. 22. Value of $\tau$ in point T4

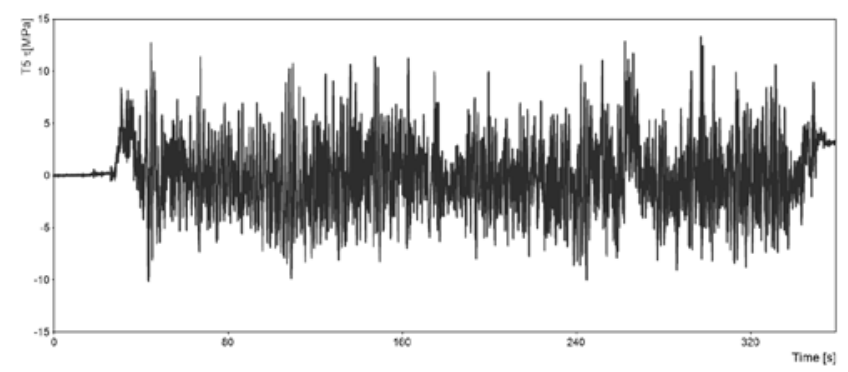

Fig. 23. Value of $\tau$ in point $T 5$

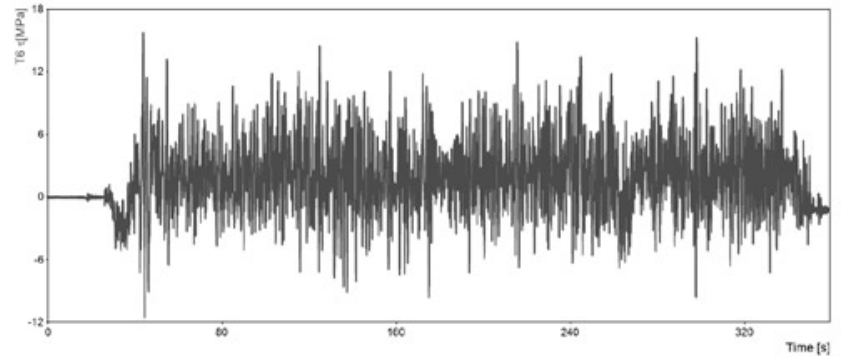

Fig. 24. Value of $\tau$ in point T6

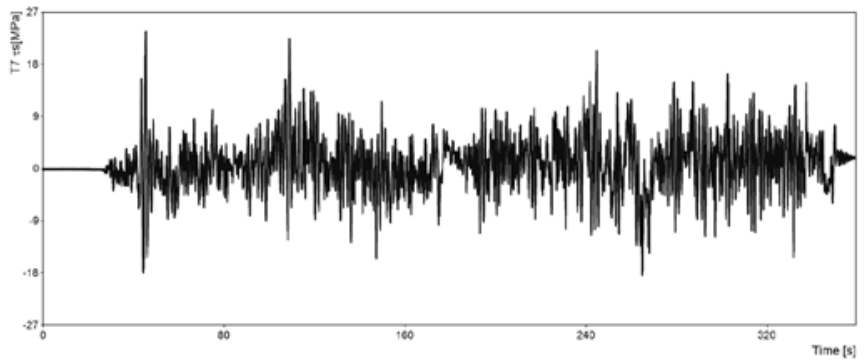

Fig. 25. Value of $\tau$ in point $T 7$

\subsection{Dynamic measurements of jointed main and auxiliary frames}

Measurements of acceleration during the off-road ride with the vehicle at eleven points were conducted. The vehicle in the first part of dynamic test was without container and in the second part was with 20 -feet container fully loaded. The total mass of container was 
Table 5. En example of maximum, minimum and the range of sheer stress value during off-road ride

\begin{tabular}{||c|c|c|c||}
\hline Measurement point & $\begin{array}{c}\boldsymbol{\tau}_{\min } \\
{[\mathrm{MPa}]}\end{array}$ & $\begin{array}{c}\boldsymbol{\tau}_{\max } \\
{[\mathrm{MPa}]}\end{array}$ & $\begin{array}{c}\Delta \boldsymbol{\tau} \\
{[\mathrm{MPa}]}\end{array}$ \\
\hline T1 & -47 & 53 & 100 \\
\hline T2 & -35 & 58 & 93 \\
\hline T3 & -29 & 37 & 66 \\
\hline T4 & -43 & 27 & 70 \\
\hline T5 & -10 & 13 & 23 \\
\hline T6 & -12 & 16 & 28 \\
\hline T7 & -18 & 24 & 42 \\
\hline
\end{tabular}

$8.72 \mathrm{Mg}$. The rigid container was connected to the chassis at four points by quick disconnect couplings. The stresses at chosen points of frames pointed in paragraph 3 were conducted as well as acceleration in eleven points of the vehicle in three dimensions.

In off-road condition the accelerations were measured when the vehicle was moving at an average speed of $16[\mathrm{~km} / \mathrm{h}]$. An example of speed variability was presented in figure 17.

The outcome value of vertical acceleration recorded in four upper corner of container was up to $11,3\left[\mathrm{~m} / \mathrm{s}^{2}\right]$ and side acceleration was up to $4,8\left[\mathrm{~m} / \mathrm{s}^{2}\right]$. An example of vertical accelerations was presented in figure 18.

An examples of stress value in chosen points of jointed frames were presented in figures $19 \div 25$. The list of recorded sheer stress value for off-road ride is presented in table 5 .

The range of twist angle of the auxiliary frame was very small because the container helps make the frame rigid. So, the connections between the main and auxiliary frame are prone to lengthening in the elastic range of deformation and this must be taken into account.

\section{Conclusions}

As pointed out above the range of twist angle of jointed frames depends on the stiffness of a body. The total twist angle of the main frame was 20,4 [deg] and was twice larger than the twist angle of jointed frames. This information is crucial because the vehicle is a high mobility class and in this case the jointed frames should be rather flexible than rigid $[6,8]$. So, if the twist stiffness of jointed frames between the front and rear container beam is quite high, the value of sheer stress in the front part of jointed frames is getting higher. That was confirmed in the tests and a necessary change of joining the two frames had to be done.

\section{References}

1. Bocian M., Jamroziak K., Kulisiewicz M., The identification of nonlinear damping of the selected components of MDOF complex vibratory systems, Proceedings of the 9th International Conference on Structural Dynamics, EURODYN 2014 Porto, Portugal, 30 June - 2 July 2014 , A. Cunha, E. Caetano, P. Ribeiro, G. Müller (eds.) Book Series: EURODYN-International Conference on Structural Dynamics 2014: $3365-3372$.

2. Buchacz A., Płaczek M., Damping of mechanical vibrations using piezoelements, including influence of connection layer's properties on the dynamic characteristic. Solid State Phenomena 2009: 147-149: 869-875, http://dx.doi.org/10.4028/www.scientific.net/SSP.147-149.869.

3. Buchacz A., Płaczek M., The analysis of a composite beam with piezoelectric actuator based on the approximate method. Journal of Vibroengineering 2012: 14; 111-116.

4. Buchacz A., Płaczek M., The approximate Galerkin's method in the vibrating mechatronic system's investigation, New face of TMCR proceedings Book series. Proceedings of the International Conference ModTech 2010: 147-150.

5. Głowacz A., Głowacz A., Korohoda P., Recognition of monochrome thermal images of synchronous motor with the application of binarization and nearest mean classifier. Archives of Metallurgy and Materials 2014: 59(1); 31-34, http://dx.doi.org/10.2478/amm-2014-0005.

6. Jamroziak K., Kosobudzki M., Determining the torsional natural frequency of underframe of off-road vehicle with use of the procedure of operational modal analysis. Journal of Vibroengineering 2012: 14(2): 472-475.

7. Lee Y. L., Pan J., Hathaway R., Barklay M., Fatig testing and analysis. Theory and practice. Burlington: Elsevier-Heinemann, 2005.

8. Reimpell J., Betzler J., Podwozia samochodów. Podstawy konstrukcji. Warszawa: WKŁ, 2008.

9. Rusiński E., Czmochowski J., Kowalczyk M., Pietrusiak D., Numerical and experimental modal modes identification methods of steel construction. Journal of Science of the Gen. Tadeusz Kosciuszko Military Academy of Land Forces 2010: 4; 208-218.

10. Rusiński E., Czmochowski J., Smolnicki T. Advanced Finite Element Method, Wroclaw: Wroclaw University of Technology, 2000.

11. Rusiński E., Koziołek S., Jamroziak K., Quality assurance method for the design and manufacturing process of armoured vehicles. Eksploatacja i Niezawodnosc - Maintenance and Reliability 2009: 3; 70-77.

12. Rybak P., Operating loads of impulse nature acting on the special equipment of the combat vehicles. Eksploatacja i Niezawodnosc Maintenance and Reliability 2014; 16(3): 347-353.

13. Smolnicki T., Karlinski J., Derlukiewicz D., Identyfication of internal stress in bolted flanged joints. Solid State Phenomena 2010: 165: 352358, http://dx.doi.org/10.4028/www.scientific.net/SSP.165.353.

14. Wong J. Y., Terramechanics and off-road vehicle engineering. Terrain behaviour, off-road vehicle performance and design. ButterworthHeinemann: Elsevier, 2010.

15. Zienkiewicz O.C., Taylor R.L. The Finite Element Method, London: McGraw Hill Book Company, 1991.

16. Żółkiewski S., Numerical application for dynamical analysis of rod and beam systems in transportation. Solid State Phenomena 2010: 164: 343-348, http://dx.doi.org/10.4028/www.scientific.net/SSP.164.343.

\author{
Mariusz KOSOBUDZKI \\ Logistics Departament \\ Gen. Tadeusz Kosciuszko Military Academy of Land Forces \\ ul. Czajkowskiego 109, 51-150 Wrocław, Poland \\ E-mail:m.kosobudzki@wso.wroc.pl
}

\author{
Mariusz STAŃCO \\ Department of Machine Design and Research \\ Wroclaw University of Technlogy \\ ul. Lukasiewicza 5 B-5, 50-370 Wrocław, Poland \\ E-mail: mariusz.stanco@pwr.edu.pl
}

